\title{
Land use change effects on breeding bird community com- position
}

\author{
JON C. BOREN, DAVID M. ENGLE, MICHAEL W. PALMER, RONALD E. MASTERS, AND TANIA CRINER
}

Authors are assistant professor, Department of Extension Animal Resources, New Mexico State University, Las Cruces, NM 88003 (at the time of the research, Boren was with the Department of Agronomy, Oklahoma State University, Stillwater, Okla. 74075); professor, Department of Agronomy; professor, Department of Botany; associate professor, Department of Forestry; and research assistant, Department of Agronomy, Oklahoma State University, Stillwater, Okla. 74075.

\begin{abstract}
We identified land uses, vegetation cover types, and landscape patterns associated with avian community diversity in $\mathbf{2}$ rural landscapes in a hardwood forest-tallgrass prairie ecotone that differ with regard to human population density. We obtained long-term ( 24 years) changes in avian community composition through records from the North American Breeding Bird Survey. We obtained historical and present land use, vegetation cover types, and landscape structure of both landscapes from high-resolution aerial photography. Avian community composition in the low density rural population landscape was primarily related to the amount of land in deciduous forest and land treated with fire or herbicides. In contrast, avian community composition in the high density rural population landscape was primarily related to the amount of land in deciduous forest, native grassland, and roads. Changes in vegetation cover type were related to changes in the avian community composition by increasing prairie habitat associated species in the low density rural population and generalist habitat associated species in the high density rural population landscapes. Loss of neotropical migrants and increased number of generalist species in the high density rural population landscape was related to decreased native vegetation, road development, and increased landscape fragmentation. Biologists and conservationists in this region should focus attention on preserving biological diversity of rural ecosystems by maintaining native plant communities.
\end{abstract}

Key Words: Agriculture, avian species, landscape structure, urbanization, vegetation cover type

Land use intensification often reduces ecosystem diversity on a regional scale due to the replacement of natural vegetation with managed systems of altered structure (Davis and Glick 1978, Krummel et al. 1987). These anthropogenic changes have caused concern about preserving and managing biological diversity (Grove and Hohmann 1992, Urban et al.

This study was approved for publication by the Director, Oklahoma Agricultura Experiment Station and funded in part by the Oklahoma Agricultural Experiment Station through project S-1822 and a grant from the Targeted Research Initiative Program.

Manuscript accepted 13 Nov. 1998.

\section{Resumen}

Identificamos los usos de la tierra, tipos de cobertura vegetal y patrones del paisaje asociados con la diversidad de la comunidad de aves de dos paisajes rurales en un ecotono de bosque de madera dura - pradera de pastos altos que difieren respecto a la densidad de población humana. A través de los registros del North American Breeding Bird Survey obtuvimos los cambios a largo plazo de la composición de la comunidad de aves. Mediante el uso de fotografía aérea de alta resolución obtuvimos el uso histórico y presente de la tierra, tipos de cobertura vegetal y estructura del paisaje en ambos tipos de paisaje. En el paisaje de baja densidad de población rural, la composición de la comunidad de aves estuvo relacionada principalmente a la cantidad de tierra en el bosque deciduo y al terreno tratado con fuego o herbicidas. En contraste, la composición de la comunidad de aves del paisaje alta densidad de población rural se relaciono principalmente a la cantidad de bosque deciduo, pastizal nativo y caminos. Los cambios de tipo de cobertura vegetal se relacionaron con cambios en la composición de la comunidad de aves, en las áreas de baja densidad de población rural mediante un incremento de especies cuyo hábitat es la pradera y en las áreas de alta densidad de población rural por el aumento de especies generalistas. La perdida de especies neotropicales migrantes y el aumento de especies generalistas registrada en el paisaje de alta densidad de población rural se relaciono con la reducción de la vegetación nativa, desarrollo de caminos y el aumento en la fragmentación del paisaje. Los biólogos y conservacionistas de esta región deben enfocar su atención en preservar la diversidad biológica de los ecosistemas rurales mediante el mantenimiento de comunidades de plantas nativas.

1992, West 1993). Management of avian diversity in urban environments has become increasingly important because of increasing urbanization, growth in non-consumptive uses, and economic returns of urban wildlife (Gill and Bonnett 1973, DeGraaf and Payne 1975, Smith 1975, George 1982). Although the effects of urbanization on many wildlife species are well documented, the dynamics of heterogeneous environments, such as the wildland to suburban ecotone, have been largely ignored by ecologists. As the human population expands, more emphasis should be placed on maintaining 
avian biodiversity to protect desirable species (Rodiek 1991). However, few studies have compared the avifauna and vegetation of urban areas with the outlying, less intensively used areas (Beissinger and Osborne 1982).

The relationship between vegetation cover types, habitat structure, and avian communities is useful for examining effects of land use on breeding birds at both stand and landscape level and should be addressed when assessing habitat quality (DeGraaf 1991, Scott et al. 1993). However, most population surveys of avian species have been at spatial scales of about 40 ha and in monocultures (Urban and Shugart 1984). Therefore, habitat management to maintain high historical diversity of avian species depends on the knowledge of changes that can or will occur in a given landscape because the landscape is a mosaic of stands and local ecosystems (DeGraaf 1991).

Implications of increasing human activity on the avifauna in the hardwood forest-tallgrass prairie ecotone must largely be extrapolated from previous studies conducted in contiguous forests (Johnson and Temple 1986). However, native birds in North America's prairies have undergone more widespread declines over the past 25 years than any other U.S. bird group, which warrants the increasing concern for the conservation of these birds (Knopf 1994). Therefore, we chose 2 rural landscapes in northern Oklahoma that differed in human population density to test the hypothesis that human activity alters avian community structure in a hardwood forest-tallgrass prairie ecotone. Specifically, we hypothesized that 1) avian community composition in a high density, rural population and a low density, rural population landscape differed in 1966 and diverged over time as the high density rural population landscape became more urbanized, and 2) different vegetation cover types between the landscapes, in part reflecting different human activities and agricultural practices, influenced avian community composition.

\section{Study Site}

Our study was centered around suburban Tulsa, Okla., and included the surrounding rural areas in northeastern
Osage and southern Washington counties. We selected 2 U.S. Fish and Wildlife Service Breeding Bird Survey routes, 024 (Collinsville) and 026 (Bartlesville) (Baumgartner and Baumgartner 1992), within the ecotonal area of the Cherokee Prairie grassland formation and oak (Quercus spp.)-hickory (Carya spp.) savanna of the Cross Timbers (Bruner 1931, Soil Conservation Service 1981). The Cherokee Prairie of Oklahoma extends as a long narrow strip, $240 \mathrm{~km}$ southward from the Kansas state line with a width of 50-100 km throughout most of its length. The strip is better adapted to support grasses, forbs, and legumes than forests because of climate and underlying geology (Harlan 1957). The Cross Timbers lie west of the Cherokee Prairie and the Lower Arkansas Valley, extending $290 \mathrm{~km}$ southward from Kansas with a width of $80 \mathrm{~km}$ wide. The region is a transitional oak forest with interspersed prairie (Bruner 1931, Gray and Galloway 1959).

Survey routes also varied in their proximity from Tulsa, a major metropolitan area in northern Oklahoma with an estimated population of 361,628 (U.S. Department of Commerce 1990). The Collinsville route is located in Washington County and the Bartlesville route is located in Osage County. A $50 \%$ increase in human use areas was observed in the Collinsville route while a $4 \%$ decrease was observed in the Bartlesville route between 1966 and 1990 (Boren et al. 1997). Human population density of Washington and Osage County in 1990 was $3,340 \mathrm{~km}^{-2}$ and 520 $\mathrm{km}^{-2}$, respectively. In addition, rural population density differed between the 2 routes. Rural population density of Washington and Osage County in 1990 was $10.3 \mathrm{~km}^{-2}$ and $4.9 \mathrm{~km}^{-2}$, respectively. Rural population is defined the by U.S. Department of Commerce (1990) as residing in communities of less than 2,500 people. Hence, from this point forward, the 2 landscapes will be discussed as high density rural population or low density rural population. Each landscape includes the breeding bird survey route $(40.2 \mathrm{~km}$ in length) and $0.8-\mathrm{km}$ on each side of the route boundary. The resulting coverage was approximately 6,430 ha for each landscape.

\section{Methods}

\section{Bird Surveys and Database Construction}

We used breeding bird survey routes from the U.S. Fish and Wildlife Service to obtain our avian diversity data. The U.S. Fish and Wildlife Service Breeding Bird Survey is the only data set that indexes the population status of many species of birds over a large geographical area and time (Bystrak 1981, Geissler and Noon 1981). Although a roadside count misses some species and is limited by road placement, the results are considered to be fairly reliable indexes for a prairie-woodland ecosystem (Baumgartner and Baumgartner 1992).

We classified avian species as neotropical migrants, temperate migrants, and residents and grouped species into 5 designations of habitat occurrence: forest, forest edge and shrubland, prairie, wetland, and developed areas. We further grouped species into foraging zones: aerial (open zones), ground and shrub (foliage $0-3 \mathrm{~m}$ ), midstory (foliage 3-10 m), canopy (foliage $>10 \mathrm{~m}$ ), bole (trunks and limbs), and water. Nesting zones included ground, shrub (0-3 m), midstory (3-10 m), canopy (>10 m), cavity, and other (variable heights and substrates). Classification of avian species was adapted from Harrison (1975), Bull and Farrand (1988), and Hamel (1992).

Bird abundances from 1967 to 1991 were segregated around 4 years (1966, 1973,1980 , and 1990) for which vegetation cover type and landscape structure data were documented from a previous study for both landscapes (Boren et al. 1997). Thus, breeding bird data from 1967 to 1970 corresponded to the 1966 landscape data, breeding bird survey data from 1971 to 1976 corresponded to the 1973 landscape data, breeding bird survey data from 1977 to 1984 corresponded to the 1980 landscape data, and breeding bird survey data from 1985 to 1991 corresponded to the 1990 landscape data. Relative abundance was then calculated for each of the 4 time periods by averaging relative abundance for the 4 years. Landscape data included land use and vegetation cover types (Table 1), and landscape structure measures included mean patch size, fractal dimension, landscape richness, Shannon diversity, dominance, contagion, and angular second moment (Boren et al. 1997). 
Table 1. Classification system used to map vegetation cover types (adapted from Stoms et al. 1983).

\begin{tabular}{|c|c|}
\hline Land use and cover type & Description \\
\hline Developed area & $\begin{array}{l}\text { Land occupied by residential, industrial, or other human struc- } \\
\text { tures and non-agricultural activities. Also includes transportation } \\
\text { and utility facilities. }\end{array}$ \\
\hline Roads & Black top, gravel, dirt roads, and driveways \\
\hline Water & Ponds, lakes, streams, and rivers \\
\hline Cropland & $\begin{array}{l}\text { Land cultivated for row crops and cereal grains but excluding } \\
\text { grazing lands }\end{array}$ \\
\hline Pasture land and hay meadows & $\begin{array}{l}\text { Includes pasture land (seeded grasslands used for grazing by } \\
\text { cattle, sheep, goats, and horses) and hay meadows }\end{array}$ \\
\hline Native grassland & Native grasslands with less than $10 \%$ cover by shrubs or trees \\
\hline Scrub forest & $\begin{array}{l}\text { Vegetation dominated }(>10 \%) \text { by cover of broadleaf hardwoods. } \\
\text { Mostly post oak (Quercus stellata) and blackjack oak (Q. mari- } \\
\text { landica) }\end{array}$ \\
\hline Brush-treated land & $\begin{array}{l}\text { Native vegetation subjected to herbicides, fire, or chaining to } \\
\text { control woody brush encroachment }\end{array}$ \\
\hline Bare ground & Land with less than $5 \%$ vegetation cover \\
\hline
\end{tabular}

\section{Data Analysis}

Avian Community Change

We performed detrended correspondence analysis (DCA) with the program CANOCO (ter Braak 1988) to determine if avian community composition differed between landscapes and to document shifts in avian community composition over time by using year as the passive environmental variable. Detrended correspondence analysis is an indirect gradient analysis in which samples (species abundances) are arranged according to species composition alone. The important environmental gradients are indirectly inferred from the trends in species abundances. The first 2 axes of the DCA ordination were selected as the main ordination framework because higher eigenvalues indicate more importance in explaining avian community variability (Table 2). Detrended correspondence analysis has the advantage of producing axes that correspond to actual ecological distances, as defined by the abundance of species, and are not forced to be equal in length (Malanson and

Trabaud 1987). We plotted the centroids for avian community composition for individual years in DCA space as points. We used these points to indicate trajectories through time in the avian space defined by the ordination axes (Whisenant and Wagstaff 1991).

We used species scores generated by DCA to determine the avian species responsible for temporal shifts in avian community composition. Visual observation of axis 1 and 2 of the ordination diagram indicated bird species (with overall abundances > 3) most responsible for temporal change in avian community composition. Therefore, DCA provided a multivariate approach to identify species that were declining or increasing within each landscape.

\section{Influence of Landscape Cover Type and Structure}

We performed canonical correspondence analysis (CCA) with the program CANOCO (ter Braak 1988) to determine the influence of vegetation cover

Table 2. Eigenvalues and cumulative variance (\%) of species data for the first $\mathbf{4}$ axes of detrended correspondence analysis on species data, with year as a passive environmental variable, in a low density rural population (extensively managed) and high density rural population (intensively managed) landscape.

\begin{tabular}{lccccc}
\hline \hline & Axis 1 & Axis 2 & Axis 3 & Axis 4 & $\begin{array}{c}\text { Total } \\
\text { inertia }\end{array}$ \\
\hline $\begin{array}{l}\text { Low density rural population } \\
\quad \text { Eigenvalue }\end{array}$ & 0.30 & 0.22 & 0.12 & 0.09 & 2.73 \\
$\quad \begin{array}{l}\text { Cumulative variance of species data (\%) } \\
\text { High density rural population }\end{array}$ & 11.1 & 18.9 & 23.5 & 26.9 & \\
$\quad \begin{array}{l}\text { Eigenvalue } \\
\quad \text { Cumulative variance of species data (\%) }\end{array}$ & 0.38 & 0.18 & 0.12 & 0.09 & 2.91 \\
\hline
\end{tabular}

type and landscape structure on the breeding bird community for each landscape. Canonical correspondence analysis is an eigenvector ordination technique for multivariate direct gradient analysis (ter Braak 1986). This technique explains community variation by detecting patterns of variation in species abundance that can best be explained by a set of environmental variables (ter Braak 1986). By applying CCA, it is possible to identify important environmental variables that explained avian community composition with no a priori knowledge about possible predictor variables (Saetersdal and Birks 1993).

We related abundances of all bird species in the high density rural population and low density rural population landscapes (100 and 86 bird species, respectively) to both vegetation cover type and landscape structure variables in separate CCA ordinations. We used forward selection and Monte Carlo permutation tests $(\mathrm{P}<0.05)$ to determine environmental variables that best explained variation in breeding bird abundances. We examined canonical coefficients and intraset correlations to evaluate relative contributions of environmental variables to the axes. We also used unrestricted Monte Carlo permutation tests for statistical significance $(\mathrm{P}<0.05)$ of the first 2 ordination axes. Tests of significance in CCA do not depend on parametric distributional assumptions; therefore, we did not transform species and environmental variables (Palmer 1993).

Canonical correspondence analysis biplots provided weighted least squares approximations of the weighted averages of species identified as causing shifts in community structure (from DCA) with respect to environmental variables (ter Braak 1986). We examined bird species relationships with a given environmental variable by continuing the environmental variable line through the origin in the biplot. A perpendicular line was then dropped from each bird species position to the variable of interest. Endpoints of the perpendicular line indicate relative positions of bird species distribution centers along the environmental variable. These endpoints indicate relative relationship of each species to a given variable (ter Braak 1986, 1987).

We used CCA with year as the only environmental axis to plot species scores of the high density rural popula- 
Table 3. Temporal changes in vegetation cover types (ha) and percent change from 1966 of high density rural population and low density rural population landscapes in a hardwood forest-tallgrass prairie ecosystem in northern Oklahoma for 1966, 1973, 1980, and 1990 (Boren et al. 1997).

\begin{tabular}{|c|c|c|c|c|c|}
\hline \multirow[t]{2}{*}{ Index } & \multicolumn{4}{|c|}{ Year } & \multirow[t]{2}{*}{ Change } \\
\hline & 1966 & 1973 & 1980 & 1990 & \\
\hline $\begin{array}{l}\text { High density rural population (Collinsville) } \\
\text { Developed areas } \\
\text { Roads } \\
\text { Water } \\
\text { Cropland } \\
\text { Pasture land and hay meadows } \\
\text { Native grassland } \\
\text { Deciduous forest } \\
\text { Brush-treated land } \\
\text { Bare ground }\end{array}$ & $\begin{array}{r}--- \\
16 \\
88 \\
53 \\
556 \\
676 \\
1,432 \\
449 \\
0 \\
2\end{array}$ & $\begin{array}{r}7 \\
92 \\
76 \\
453 \\
672 \\
1,601 \\
294 \\
41 \\
6\end{array}$ & $\begin{array}{r}25 \\
101 \\
58 \\
208 \\
850 \\
1,546 \\
398 \\
4 \\
2\end{array}$ & $\begin{array}{r}24 \\
87 \\
71 \\
120 \\
999 \\
1,508 \\
377 \\
5 \\
2\end{array}$ & $\begin{array}{r}\%) \\
50 \\
-1 \\
34 \\
-78 \\
48 \\
5 \\
-16 \\
0\end{array}$ \\
\hline $\begin{array}{l}\text { Low density rural population (Bartlesville) } \\
\text { Developed areas } \\
\text { Roads } \\
\text { Water } \\
\text { Cropland } \\
\text { Pasture land and hay meadows }\end{array}$ & $\begin{array}{r}23 \\
108 \\
27 \\
25 \\
90\end{array}$ & $\begin{array}{l}18 \\
94 \\
39 \\
41 \\
50\end{array}$ & $\begin{array}{r}16 \\
121 \\
30 \\
12 \\
25\end{array}$ & $\begin{array}{r}22 \\
118 \\
38 \\
13 \\
49\end{array}$ & $\begin{array}{r}-4 \\
9 \\
41 \\
-48 \\
-46\end{array}$ \\
\hline $\begin{array}{l}\text { Native grassland } \\
\text { Deciduous forest } \\
\text { Brush-treated land } \\
\text { Bare ground }\end{array}$ & $\begin{array}{r}1,375 \\
1,184 \\
397 \\
20\end{array}$ & $\begin{array}{r}1,308 \\
980 \\
616 \\
7\end{array}$ & $\begin{array}{r}1,120 \\
950 \\
877 \\
10\end{array}$ & $\begin{array}{r}1,117 \\
887 \\
878 \\
8\end{array}$ & $\begin{array}{l}-19 \\
-26 \\
121 \\
-60\end{array}$ \\
\hline
\end{tabular}

tion landscape against the low density rural population landscape to document divergence of avian communities. If the avian communities of the 2 landscapes were diverging in opposite directions, a negative relationship should exist. In addition, we used CCA with vegetation cover types and landscape structure as covariables and year as environmental variables to measure residual variation. If changes occur over time, some other environmental variables that were not examined in our study were affecting avian community composition.

\section{Results and Discussion}

\section{Vegetation Cover Types and Landscape Structure}

Differences in human population density and agriculture intensification in these 2 rural landscapes resulted in altered land ownership patterns and management practices that created contrasting vegetation cover types (Table 3) and landscape structure (Table 4) between the low density rural population and high density rural population landscapes (Boren et al. 1997). Land in the high density rural population landscape was subjected to intensive management practices on cropland, pasture land, and hay meadows while land in the low density rural population landscape was predominately in native vegetation ty rural population landscape became more diverse since 1966.

\section{Avian Community Change}

The trajectories of points over time (centroids of avian community composition) indicate that the avian community in the high density rural population and low density rural population landscapes diverged along axis 1 and declined along axis 2 (Fig. 1). In addition, the 2 landscapes differ from each other in avian community composition, even ignoring temporal change, which is not surprising considering differences in land use and vegetation cover types between landscapes. The trajectory of both communities progressively diverged over time, but change was greater for the avian community in the low density rural population landscape. Centroid values for the avian community in the low density rural population landscape between 1966 and 1990 changed by 0.42 and 0.20 SD units for axis 1 and 2, respectively. This suggests avian community composition was strongly affected by a temporal decrease in deciduous woodlands by prescribed burning and herbicide application to maintain tallgrass prairie in the low density rural population landscape (Boren et al. 1997). Centroid values for the avian community in the high density rural population landscape between 1966 and 1990 were only 0.20 and 0.20 SD units apart for axis 1 and 2, respectively. Species scores from CCA, with year as the only variable, of the high density rural population landscape had a negative relationship with the species scores of the low density rural population landscape.

Table 4. Measures of landscape structure and percent change from 1966 of high density rural population and low density rural population landscapes in a hardwood forest-tallgrass prairie ecosystem in northern Oklahoma for 1966, 1973, 1980, and 1990 (Boren et al. 1997).

\begin{tabular}{|c|c|c|c|c|c|}
\hline \multirow[t]{2}{*}{ Index } & \multicolumn{4}{|c|}{ Year } & \multirow[t]{2}{*}{ Change } \\
\hline & 1966 & 1973 & 1980 & 1990 & \\
\hline High density rural population (Collinsville) & \multicolumn{4}{|c|}{ - - - - - - - - - (ha) - - - - - - - - - - } & $(\%)$ \\
\hline Mean patch size (ha) & 4.16 & 3.93 & 3.22 & 2.96 & -29 \\
\hline Fractal dimension & 1.23 & 1.25 & 1.27 & 1.28 & +4 \\
\hline Shannon diversity & 1.43 & 1.39 & 1.33 & 1.28 & -11 \\
\hline Dominance & 0.65 & 0.75 & 0.81 & 0.86 & +3 \\
\hline Contagion & 2.69 & 2.83 & 2.85 & 2.91 & +8 \\
\hline Angular second moment & 0.27 & 0.30 & 0.30 & 0.32 & +19 \\
\hline Contrast & 0.33 & 0.46 & 0.50 & 0.50 & +52 \\
\hline \multicolumn{6}{|l|}{ Low density rural population (Bartlesville) } \\
\hline Mean patch size (ha) & 3.96 & 4.29 & 3.63 & 3.42 & -8 \\
\hline Fractal dimension & 1.27 & 1.24 & 1.27 & 1.30 & +2 \\
\hline Shannon diversity & 1.21 & 1.29 & 1.29 & 1.31 & +8 \\
\hline Dominance & 0.93 & 0.78 & 0.78 & 0.83 & -11 \\
\hline Contagion & 2.99 & 2.82 & 2.81 & 2.88 & -4 \\
\hline Angular second moment & 0.35 & 0.30 & 0.29 & 0.29 & -17 \\
\hline Contrast & 0.41 & 0.35 & 0.35 & 0.42 & +2 \\
\hline
\end{tabular}




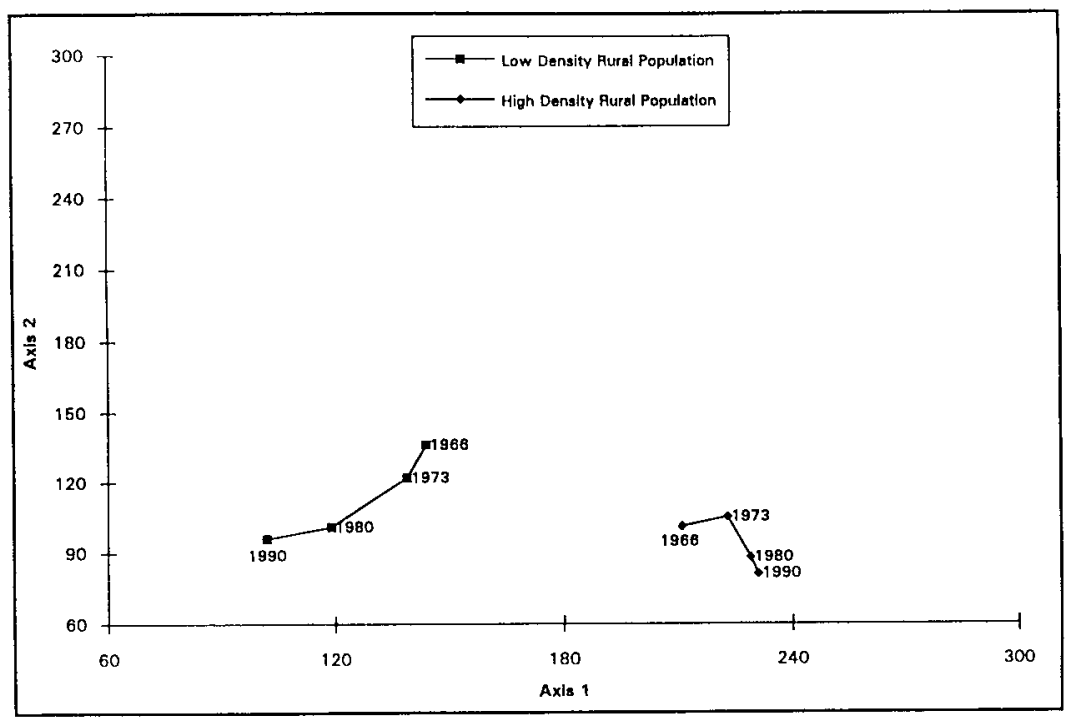

Fig. 1. Detrended correspondence analysis (DCA) ordination of centroids for avian community composition in the low density rural population (extensively managed) and high density rural population (intensively managed) landscapes. Lines indicate trajectories of avian community change between 1966 and 1990 defined by the ordination axes.

This confirms the DCA results that the avian communities were diverging in opposite directions over time (Fig. 2).

Detrended correspondence analysis provides a scaling of axes in units of compositional turnover (SD units; Hill and Gauch 1980). This scaling provides a robust estimate of beta diversity (Okland et al. 1990) that reflects rate of change in community composition along a gradient (Wilson and Mohler 1983, Samson and Knopf 1993). Based on the small SD axis units, both avian communities exhibited low beta diversity with relatively small temporal movement along axis 1 (Fig. 1). Therefore, change or turnover in avian community species composition in the low density rural population and high density rural population landscapes was relatively slow between 1966 and 1990 .

Although the avian community in the high density rural population and low density rural population landscapes diverged over time, the great-tailed grackle (Quiscalus mexicanus) and rock dove (Columba livia) increased in both landscapes (Table 5). This suggests a temporal increase in some generalist species by immigration from nearby source habitats. An aggressive trap and transplant program most likely accounted for the observed increase of wild turkey (Meleagris gallopavo) in both landscapes. We observed none of the 10 species endemic to grasslands (Knopf 1994) in our study area. However, density rural population landscape $\left(\mathbf{r}^{2}=0.13, \mathrm{P}<0.05\right)$. prefers vegetation about $30 \mathrm{~cm}$ tall (Hamel 1992). However, the grasshopper sparrow is sensitive to small changes in its habitat. When herbaceous material becomes too thick or trees encroach on prairies and abandoned fields, these habitats become unsuitable as breeding sites (Bull and Farrand 1988). The dickcissel also requires herbaceous cover (about $60 \mathrm{~cm}$ tall) for breeding (Hamel 1992). Therefore, prescribed burning and herbivory related to cattle grazing in the low density rural population landscape favored these species by maintaining breeding habitat. The eastern meadowlark (Sturnella magna) and lark sparrow (Calamospiza melanocorys), species of high concern, exhibited relatively little change in both landscapes.

The yellow-breasted chat (Icteria virens), an edge species of high concern that requires dense thickets and brush for nesting habitat (Bull and Farrand 1988), declined in both landscapes. The conversion of deciduous forests to brush-treated lands in the low density rural population landscape and to pasture land and hay meadows in the high density rural population landscape from 1966 to 1990 (Boren et al. 1997) may account for the decline of this species in both landscapes. The greater prairie chicken (Tympanuchus capido) declined only in the high density rural population landscape where brush-treated land accounted for only $1 \%$ of the total area (Boren et al. 1997). This species nests in

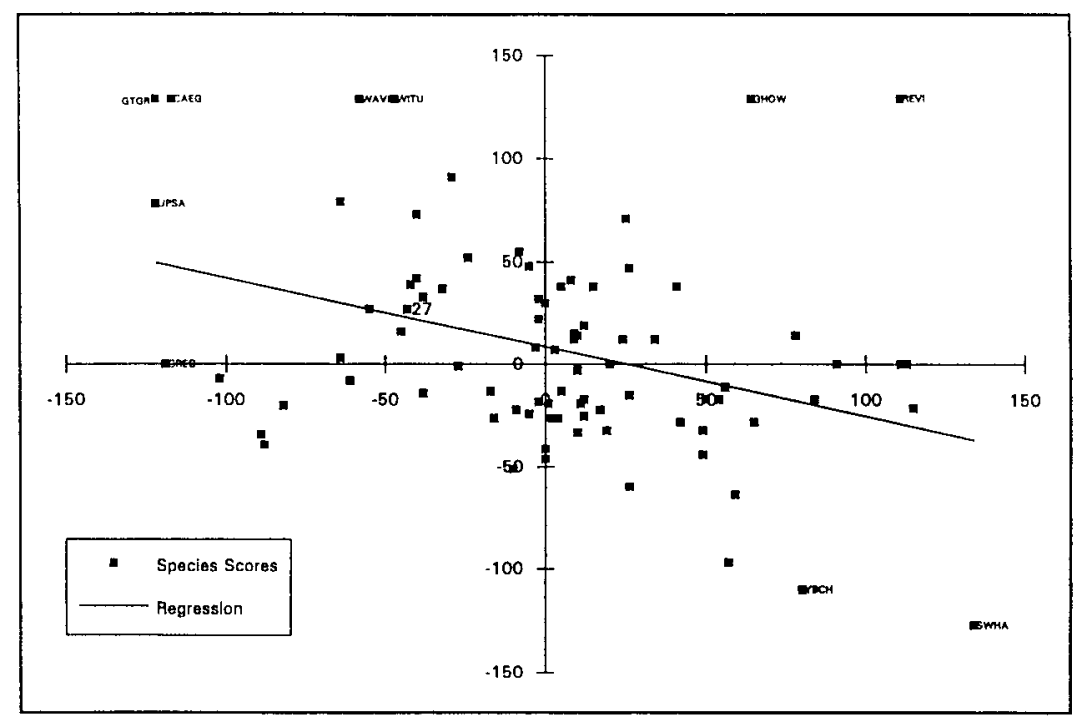

Fig. 2. Species scores from canonical correspondence analysis (CCA), with year as the only variable, of the high density rural population landscape against the plotted species scores of the low 
Table 5. Avian species responsible for shifts in avian community composition in a low density rural population (extensively managed) and high density rural population (intensively managed) landscape over a 24-year period, 1966 to 1990. Minor species (those that occurred 3 or fewer times) were omitted.

\begin{tabular}{|c|c|c|c|c|c|c|c|}
\hline$\overline{\text { Species }}$ & Code & Scientific name & Type $^{\mathrm{a}}$ & Habitat $^{\mathrm{b}}$ & Concern $^{\mathrm{c}}$ & Foraging $^{\mathrm{d}}$ & Nesting $^{\mathrm{e}}$ \\
\hline \multicolumn{8}{|l|}{ Low density rural population } \\
\hline \multicolumn{8}{|l|}{ Loss } \\
\hline Yellow-breasted chat & YBCH & Icteria virens & Neotrop & Edge & High & Ground & Shrub \\
\hline Blue-gray gnatchatcher & BGGN & Polioptila caerulea & Neotrop & Edge & Moderate & Canopy & Midstory \\
\hline Greater roadrunner & GRRO & Geococcyx californianu & Resident & Prairie & High & Ground & Shrub \\
\hline Bewickís wren & BEWR & Thryomanes bewickii & Temp & Edge & High & Ground & Cavity \\
\hline Black and white warbler & BAWW & Mniotilta varia & Neotrop & Forest & Moderate & Midstory & Ground \\
\hline Field sparrow & FISP & Spizella pusilla & Temp & Edge & High & Ground & Ground \\
\hline Painted bunting & PABU & Passerina ciris & Neotrop & Edge & High & Ground & Shrub \\
\hline Pileated woodpecker & PIWO & Dryocopus pileatus & Resident & Forest & Moderate & Bole & Cavity \\
\hline Summer tanager & SUTA & Piranga rubra & Neotrop & Forest & High & Midstory & Midstory \\
\hline Eastern tufted titmouse & ETTI & Parus bicolor & Resident & Forest & High & Midstory & Cavity \\
\hline White-breasted nuthatch & WBNU & Sitta carolinensis & Resident & Edge & Moderate & Bole & Cavity \\
\hline \multicolumn{8}{|l|}{ Gain } \\
\hline Dickcissel & DICK & Spiza americana & Neotrop & Prairie & High & Ground & Ground \\
\hline Wild turkey & WITU & Meleagris gallopavo & Resident & Edge & High & Ground & Ground \\
\hline Barn swallow & BARS & Hirundo rustica & Neotrop & Develop & Moderate & Aerial & Other \\
\hline Grasshopper sparrow & GRSP & Ammodramus savannarum & Neotrop & Prairie & High & Ground & Ground \\
\hline Great-tailed grackle & GTGR & Quiscalus mexicanus & Resident & Edge & Moderate & Ground & Shrub \\
\hline Little blue heron & LBHE & Egretta caerulea & Temp & Water & Moderate & Water & Shrub \\
\hline Rock dove & RODO & Columba livia & Resident & Develop & Low & Ground & Other \\
\hline Black-billed cucko & BBCU & Coccyzus erythropthaim & Neotrop & Edge & High & Midstory & Shrub \\
\hline Cattle egret & CAEG & Bubulcus ibis & Resident & Prairie & Low & Ground & Shrub \\
\hline Yellow-breasted chat & YBCH & Icteria virens & Neotrop & Edge & High & Ground & Shrub \\
\hline Chipping sparrow & CHSP & Spizella passerina & Neotrop & Forest & Moderate & Ground & Shrub \\
\hline Common yellowthroat & COYE & Geothlypis trichas & Neotrop & Edge & Moderate & Ground & Shrub \\
\hline Great-horned Owl & GHOW & Bubo virginianus & Resident & Edge & Moderate & Ground & Cavity \\
\hline Greater prairie chicken & GPCH & Tympanuchus capido & Resident & Prairie & High & Ground & Ground \\
\hline Kentucky warbler & KEWA & Oporornis formosus & Neotrop & Forest & High & Ground & Ground \\
\hline Northern-parula warbler & NOPA & Parula americana & Neotrop & Forest & High & Midstory & Canopy \\
\hline Red-shouldered hawk & RSHA & Buteo lineatus & Temp & Edge & Moderate & Ground & Canopy \\
\hline Yellow-bellied sapsucker & YBSA & Sphyrapicus sp. & Temp & Edge & High & Bole & Cavity \\
\hline \multicolumn{8}{|l|}{ Gain } \\
\hline American robin & AMRO & Turdus migratorius & Temp & Develop & Low & Ground & Shrub \\
\hline Gray catbird & GRCA & Dumetella carolinensis & Neotrop & Edge & High & Ground & Shrub \\
\hline Common grackle & COGR & Quiscalus quiscula & Resident & Edge & Low & Ground & Midstory \\
\hline Great-tailed grackle & GTGR & Quiscalus mexicanus & Resident & Edge & Moderate & Ground & Shrub \\
\hline House sparrow & HOSP & Passer domesticus & Resident & Develop & Low & Ground & Cavity \\
\hline Purple martin & PUMA & Progne subis & Neotrop & Develop & Moderate & Aerial & Cavity \\
\hline Rock dove & RODO & Columba livia & Resident & Develop & Low & Ground & Other \\
\hline European starling & EUST & Sturnus vulgaris & Resident & Develop & Low & Ground & Cavity \\
\hline Wild turkey & WITU & Meleagris gallopavo & Resident & Edge & High & Ground & Ground \\
\hline
\end{tabular}

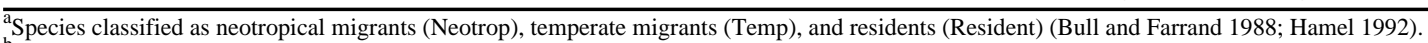

${ }^{\mathrm{b}}$ Species grouped into designations of habitat occurrence: forest (Forest), forest edge and shrubland (Edge), prairie (Prairie), and developed areas (Developed) (Bull and Farrand 1988; Hamel 1992).

${ }^{c}$ Species grouped into population trends: low concern (Low), moderate concern (Moderate), and high concern (High).

${ }^{\mathrm{d}}$ Species grouped into foraging zones: open zones (Aerial), foliage 0-3 m (Ground), foliage 3-10 m (Midstory), and trunks and limbs (Bole) (Bull and Farrand 1988; Hamel 1992).

'Species grouped into nesting zones: ground (Ground), 0-3 m (Shrub), 3-10 m (Midstory), > $10 \mathrm{~m}$ (Canopy), cavity (Cavity), and variable heights and substrates (Other) (Harrison 1975).

habitats of standing residual vegetation from a preceding growing season and is dependent upon stand rejuvenation by fire (Kirsch 1974).

We observed a greater loss of neotropical migrants from the high density rural population landscape compared to the low density rural population landscape (33\% and $3 \%$, respectively), which can be attributed to differences in land use and associated management practices. The ratio of neotropical migrants to resident/temperate migrants shifted from $1.2: 1$ to $0.75: 1$ in the low density rural population landscape and from $1.2: 1$ to
$0.29: 1$ in the high density rural population landscape. Changes in neotropical migrant diversity and density by urban sprawl result from human-induced changes in vegetation composition. However, recent scientific studies suggest that the primary factors limiting neotropical migrants are related to fragmentation and edge effect as opposed to habitat loss (Hagan and Johnston 1992, Faaborg et al. 1993, Maurer and Heywood 1993, Thompson et al. 1993).

Landscape quality, especially with regard to landscape fragmentation and diversity, continued to erode between
1966 and 1990 in the high density rural population landscape (Boren et al. 1997), which may account for the observed loss of neotropical migrants from the high density rural population landscape. Problems associated with habitat fragmentation include increased edge habitat, parasitism rates, predation rates, and isolation effects which generally have adverse effects on neotropical migrant species (Johnson and Temple 1986, Faaborg et al. 1993). Our data also suggest that biological diversity and ecological integrity of the high density rural population landscape are lower 
Table 6. Eigenvalues, correlation coefficients, and cumulative variances (\%) between species and environmental axes for stepwise canonical correspondence analyses carried out on landscape cover type and landscape structure variables in a low density rural population (extensively managed) and high density rural population (intensively managed) landscape.

\begin{tabular}{|c|c|c|c|c|}
\hline & \multicolumn{2}{|c|}{ Vegetation cover type } & \multicolumn{2}{|c|}{ Landscape structure } \\
\hline & Axis 1 & Axis 2 & Axis 1 & Axis 2 \\
\hline \multicolumn{5}{|l|}{ Low density rural population } \\
\hline Eigenvalue $^{\mathrm{a}}$ & 0.18 & 0.12 & 0.08 & 0.05 \\
\hline Species-environment correlation ${ }^{\mathrm{b}}$ & 0.80 & 0.74 & 0.55 & 0.55 \\
\hline Cumulative variance explained $(\%)^{\mathrm{c}}$ & 43.1 & 70.6 & 43.4 & 68.8 \\
\hline Sum of all canonical eigenvalues ${ }^{\mathrm{d}}$ & 0.43 & & 0.18 & \\
\hline Total inertia & 2.74 & & 2.74 & \\
\hline \multicolumn{5}{|l|}{ High density rural population } \\
\hline Eigenvaluea & 0.28 & 0.05 & 0.09 & 0.06 \\
\hline Species-environment correlationb & 0.88 & 0.60 & 0.59 & 0.52 \\
\hline Cumulative variance explained (\%)c & 65.1 & 77.6 & 41.5 & 68.2 \\
\hline Sum of all canonical eigenvaluesd & 0.44 & & 0.21 & \\
\hline Total inertia & 2.91 & & 2.91 & \\
\hline
\end{tabular}

aigenvalues $(\lambda)$ measure the importance of the ordination axis.

${ }^{b}$ Species-environment correlation $(r)$ is a measure of how well the extracted variation in community composition can be explained by the environmental variables.

${ }_{d}^{c}$ Cumulative percentage variance of species-environment relation.

${ }^{d}$ Sum of all canonical eigenvalues represents the total amount of extracted variation accounted for by the CCA ordination.

compared to the rural landscape. Neotropical migratory birds provide ideal indices of ecological integrity because they are highly sensitive to changes in landscapes that compromise the spatial continuity and integrity of natural ecosystems (Maurer 1993). However, indices of biological diversity must take into account the dynamic nature of ecosystems and include ecological processes occurring outside the area of interest (Landres 1992).

Differences in avian nesting and foraging zones between landscapes can be attributed to differences in land use and associated management practices. Prescribed burning, herbicide application, and grazing management resulted in a $26 \%$ reduction of deciduous woodland in the low density rural population landscape (Boren et al. 1997). Avian community in the low density rural population landscape shifted from tree nesting species (55\% reduction) to ground and shrub nesters, which supports our observed reduction of tree foraging to ground foraging species in the low density rural population landscape. However, shifts in nesting and foraging zones are not as apparent in the high density rural population landscape. In addition, changes in vegetation cover type was related to changes in the avian community composition by decreasing some forest and edge species in both landscapes relative to prairie and generalist species in the low density rural population and high density rural population landscapes, respectively. including forest (17\%), cropland (9\%), water (5\%), developed area (4\%), brushtreated land $(2 \%)$, and roads $(2 \%)$. Forward selection also identified 5 land use and vegetation cover type variables $(\mathrm{P}<0.05)$ that explained $38 \%$ of variation in breeding bird abundances in the high density rural population landscape including forest (25\%), cropland (4\%), roads $(4 \%)$, water (3\%), and native grasslands $(2 \%)$. Both axes were significant $(\mathrm{P}$ $<0.01$ ) for both landscapes according to Monte Carlo permutation tests.

The relative importance of each environmental variable for predicting the community composition can be found through analysis of canonical coefficients and intraset correlations (ter Braak 1986). Canonical coefficients define the ordination axes as linear combinations of the environmental variables. Intraset correlations are the correlation coefficients between the variables and the axes (ter Braak 1986). Canonical coefficients describe the partial or residual variation and are essentially equivalent to regression coefficients. However, with intraset correlations other variables are assumed to covary with that one environmental variable in the particular way they do in the data set and thus should be used in a multivariate environment. The ordination diagram shows the relationships between the avian community in terms of main axes of variation (Kalkhoven and Opdam 1984).

The variables most correlated with axis 1, based on intraset correlations (Table 7), of the low density rural population landscape were forest and brushtreated land. Thus, axis 1 separated species that decreased and were dependent on deciduous woodland cover [e.g., black and white warbler (Mniotilta varia), pileated woodpecker (Dryocopus pileatus), summer tanager (Piranga rubra), and eastern tufted titmouse (Parus bicolor)] from species that increased and required more open canopy and fewer trees (e.g., barn swallow (Hirundo rustica), dickcissel, and grasshopper sparrow) (Fig. 3).

The variables most correlated with axis 1 of the high density rural population landscape were forest and native grassland (Table 7). Axis 1 separated forest and shrubland species [e.g., chipping sparrow (Spizella passerina), Kentucky warbler (Oporornis formosus), and northern parula warbler 


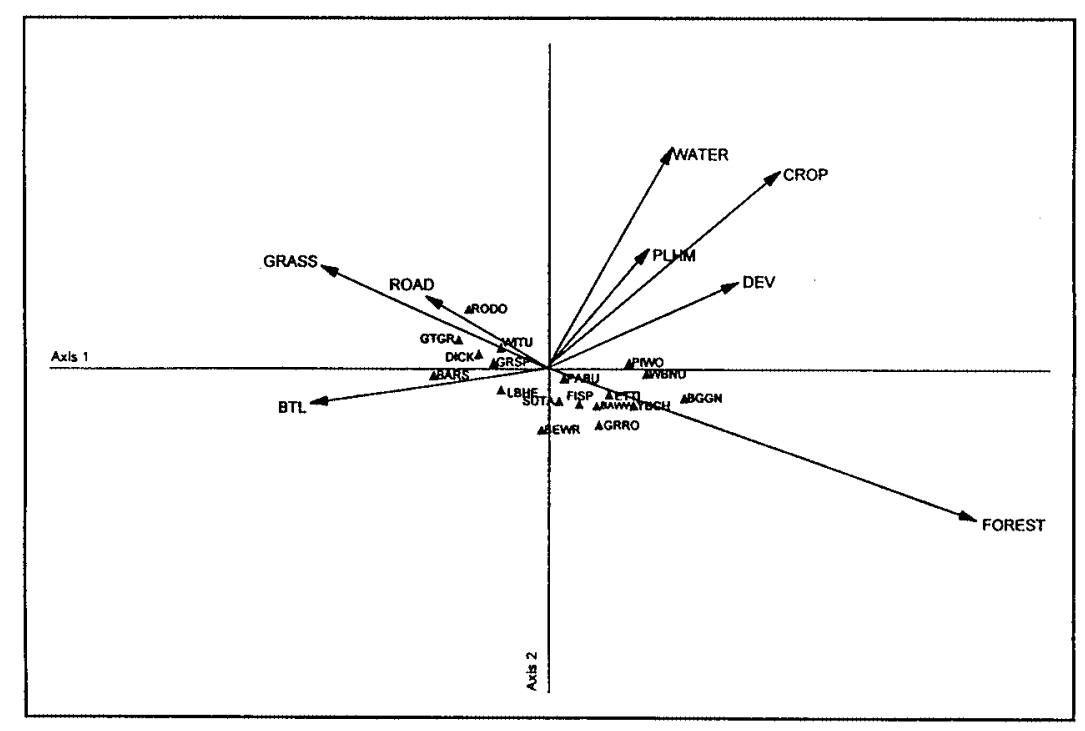

Fig. 3. Distribution of 18 species of birds in the low density rural population (extensively managed) landscape. Canonical correspondence analysis (CCA) ordination diagram with birds $(\triangle)$ and environmental variables (vegetation cover types; arrows). The bird species are: $\mathrm{YBCH}=$ yellowbreasted chat, BGGN = blue-gray gnatchatcher, GRRO = greater roadrunner, BEWR = bewickís wren, BAWW = black and white warbler, FISP = field sparrow, $\mathrm{PABU}=$ painted bunting, PIWO = pileated woodpecker, SUTA = summer tanager, ETTI = eastern tufted titmouse, $\mathrm{WBNU}=$ white-breasted nuthatch, DICK = dickcissel, WITU = wild turkey, BARS = barn swallow, GRSP = grasshopper sparrow, GTGR = great-tailed grackle, LBHE = little blue heron, and RODO = rock dove. Environmental variables are: $D E V=$ developed area, ROAD = road, WATER = water, CROP = cropland, PLHM = pasture land and hay meadows, GRASS = native grassland, FOREST $=$ scrub forest , and $\mathrm{BTL}=$ brush-treated land. influence of urban sprawl on rural avifauna must be made with caution. High mobility of birds makes them less dependent on local conditions than sedentary species and avian community composition may be influenced by surrounding bird communities (Jarvinen and Vaisanen 1980).

\section{Landscape Structure}

The CCA ordination explained approximately 18 and $21 \%$ of the variation associated with the relationship between the landscape structure and the low density rural population and high density rural population avian data sets, respectively (Table 6). Because vegetation cover types explained more than twice the variation of the avian data set compared to the landscape structure variables, vegetation cover type ordinations better explain temporal changes in avian community composition in this study. At the landscape scale, avian community composition is a function of vegetation structure (physiognomy) while at the within-stand level, particular plant taxonomic composition (floristics) is more important than structure in
(Parula americana)] from species preferring open grasslands (e.g., greater prairie chicken) (Fig. 4). Roads and grassland were most correlated with axis 2 of the high density rural population landscape. Axis 2 separated generalist species that increased and are commonly associated with human development [e.g., American robin (Turdus migratorius), house sparrow (Passer domesticus), purple martin (Progne subis), rock dove, and European starling (Sturnus vulgaris)] from prairie species which declined and are associated with less human disturbance [e.g., greater prairie chicken and cattle egret (Bubulcus ibis)] (Fig. 4).

Different vegetation cover types between the landscapes influenced avian community composition in this study. Avian community composition was primarily related to deciduous forest and brush-treated land in the low density rural population landscape compared to deciduous forest, native grassland, and roads in the high density rural population landscape. Continued urban sprawl into rural landscapes may result in increased generalist species as the result of increased roads and decreased native grassland. However, inferences on the

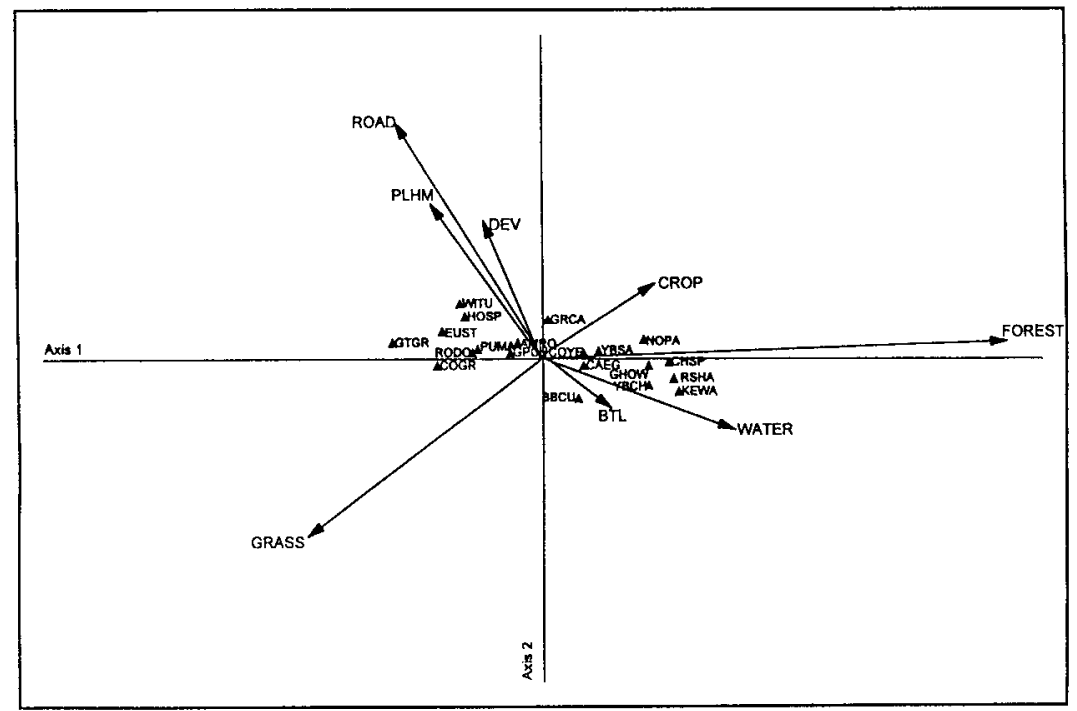

Fig. 4. Distribution of 20 species of birds in the high density rural population (intensively managed) landscape. Canonical correspondence analysis (CCA) ordination diagram with birds $(\triangle)$ and environmental variables (vegetation cover types; arrows). The bird species are: $\mathrm{BBCU}=$ blackbilled cucko, CAEG = cattle egret, $\mathrm{YBCH}=$ yellow-breasted chat, $\mathrm{CHSP}$ = chipping sparrow, COYE $=$ common yellowthroat, GHOW $=$ great-horned owl, GPCH $=$ greater prairie chicken, KEWA = Kentucky warbler, NOPA = northern-parula warbler, RSHA = red-shouldered hawk, YBSA = yellow-bellied sapsucker, AMRO = American robin, GRCA = gray catbird, COGR = common grackle, GTGR = great-tailed grackle, HOSP = house sparrow, PUMA = purple martin, RODO = rock dove, EUST $=$ European starling, and WITU = wild turkey. Environmental variables are: $\mathrm{DEV}=$ developed area, $\mathrm{ROAD}=$ road, WATER $=$ water, $\mathrm{CROP}=$ cropland, PLHM = pasture land and hay meadows, GRASS = native grassland, FOREST = scrub forest, and $\mathrm{BTL}=$ brush-treated land. 
Table 7. Canonical coefficients and intraset correlations for variables of the stepwise canonical correspondence analysis carried out on landscape cover type and structure in a low density rural population (extensively managed) and high density rural population (intensively managed) landscape.

\begin{tabular}{|c|c|c|c|c|}
\hline & \multicolumn{2}{|c|}{ Canonical coefficients } & \multicolumn{2}{|c|}{ Intraset correlations } \\
\hline & Axis 1 & Axis 2 & Axis 1 & Axis 2 \\
\hline \multicolumn{5}{|l|}{ Low density rural population } \\
\hline \multicolumn{5}{|l|}{ Vegetation covery types } \\
\hline Developed area & 0.1886 & 0.3512 & 0.3773 & 0.2696 \\
\hline Cropland & 0.2381 & 0.5417 & 0.4600 & 0.5967 \\
\hline Pasture land/hay meadows & 0.0137 & 0.0671 & 0.2043 & 0.3519 \\
\hline Native grassland & -0.3543 & 0.1984 & -0.4498 & 0.3153 \\
\hline Scrub forest & 0.4993 & -0.4171 & 0.8592 & -0.4816 \\
\hline Brush-treated land & -0.3345 & 0.0373 & -0.4836 & -0.1067 \\
\hline Roads & -0.0772 & 0.1264 & -0.2431 & 0.2208 \\
\hline Water & 0.1993 & 0.4134 & 0.2424 & 0.6642 \\
\hline Bare ground & -0.0204 & 0.0211 & 0.0368 & -0.1659 \\
\hline \multicolumn{5}{|l|}{ Landscape structure } \\
\hline Mean patch size & 0.2962 & -0.1888 & 0.6066 & -0.3657 \\
\hline Fractal dimension & 0.3953 & 0.3719 & 0.1616 & 0.5995 \\
\hline Richness & -0.6962 & 3.8510 & -0.6140 & 0.5035 \\
\hline Shannon diversity & -0.9746 & -4.4340 & -0.5840 & 0.2190 \\
\hline Dominance & -1.2727 & -4.0655 & 0.2108 & 0.0841 \\
\hline Contagion & 1.3820 & -0.4068 & 0.2636 & 0.4771 \\
\hline Angular second moment & -0.4582 & 1.0816 & 0.7338 & 0.2551 \\
\hline \multicolumn{5}{|l|}{ High density rural population } \\
\hline \multicolumn{5}{|l|}{ Vegetation cover types } \\
\hline Developed area & -0.0909 & 0.2804 & -0.1122 & 0.4117 \\
\hline Cropland & -0.1380 & 0.2842 & 0.2237 & 0.2307 \\
\hline Pasture land/hay meadows & -0.4134 & 0.4857 & -0.2183 & 0.4710 \\
\hline Native grassland & -0.6146 & -0.0212 & -0.4644 & -0.5497 \\
\hline Scrub forest & 0.5798 & 0.2718 & 0.9362 & 0.0521 \\
\hline Brush-treated land & 0.0144 & -0.0606 & 0.1327 & -0.1508 \\
\hline Roads & -0.0822 & 0.6983 & -0.2805 & 0.7025 \\
\hline Water & 0.2035 & 0.0395 & 0.3795 & -0.2206 \\
\hline Bare ground & -0.0030 & -0.3156 & 0.0046 & -0.2329 \\
\hline \multicolumn{5}{|l|}{ Landscape structure } \\
\hline Mean patch size & 0.5554 & 0.4059 & 0.8089 & 0.3836 \\
\hline Fractal dimension & -0.0703 & -0.3182 & -0.3795 & -0.2690 \\
\hline Richness & -0.4051 & 2.1382 & -0.4256 & -0.4442 \\
\hline Shannon diversity & -0.1789 & -0.6500 & -0.7334 & -0.1809 \\
\hline Dominance & 0.0057 & 0.1669 & 0.6437 & -0.1278 \\
\hline Contagion & 0.8441 & -2.8708 & 0.6586 & -0.4575 \\
\hline Angular second moment & -0.4587 & 2.3910 & 0.7392 & 0.1250 \\
\hline
\end{tabular}

determining avian community composition (Rotenberry 1985). However, Flather and Sauer (1996) concluded resident species showed few correlations with landscape structure in the eastern United States. In addition, most biodiversity studies focused on forests or woodland areas, but little research was conducted in the tallgrass prairie ecosystem. Our results support Roth (1976) and Wiens (1974) comments that generalizations relating vegetation structure and complexity to avian community composition were unrealistic for grasslands. While brush and forests vary broadly in vegetation structure and composition, which correlate with avian diversity, the degree of variability of heterogeneity among grasslands at the landscape scale is so subtle that its affect on avian diversity can be obscured (Knick and of some prairie species in the low density rural population and generalist associated species in the high density rural population landscapes. To preserve prairie birds and maintain biological diversity of prairie bird assemblages, management practices should increase the abundance and quality of native plant communities, especially grasslands. Maintenance of the tallgrass prairie by prescribed burning, judicious herbicide use for control of exotic and invasive plants, and grazing management are generally conducive to this objective. However, intensive land uses and management practices associated with areas surrounding urban centers pose a threat to the integrity of native plant communities. Although different variables explained avian community composition in the 2 landscapes, management practices that alter landscape structure may have less impact on avian community composition than changes in vegetation cover types.

Hence, biologists and conservationists in this region should focus attention on preserving biological diversity of rural ecosystems by maintaining native plant communities. In $1989,74 \%$ of the United States population resided in urban areas, and that number is expected to increase to $>80 \%$ by the year 2025 (Haub and Kent 1989). Considering the growth of metropolitan areas in the United States, knowledge of ecosystems under the influence of urbanization can only become increasingly important (McDonnell and Pickett 1990). In the absence of societal pressure to halt urban sprawl and agricultural intensification in rural landscapes, ecosystem integrity and bird communities may continue to degrade.

\section{Conclusions and Management Implications}

Changes in land use and vegetation cover types were related to changes in the avian community composition in this study. Avian communities in the high density rural population (intensively managed) and low density rural population (extensively managed) landscapes diverged over time because of different land use and management practices associated with each landscape. Temporal shifts in avian community composition were reflected in increases

\section{Literature Cited}

Avery, M.I. 1989. Effects of upland afforestation on some birds of the adjacent moorlands. J. Appl. Ecol. 26:957-966.

Baumgartner F.M., and A.M. Baumgartner. 1992. Oklahoma bird life. Univ. Okla. Press, Norman, Okla.

Beissinger, S.R. and D.R. Osborne. 1982. Effects of urbanization on avian community organization. Condor 84:75-83.

Boren, J.C., D.M. Engle, M.S. Gregory, R. E. Masters, T.G. Bidwell, and V.A. Mast. 1997. Landscape structure and change in a hardwood forest-tallgrass prairie ecotone. J. Range Manage. 50:244-249. 
Bruner, W.E. 1931. The vegetation of Oklahoma. Ecol. Monogr. 1:99-188.

Bull, J. and J. Farrand, Jr. 1988. The Audubon Society field guide to North American birds. Alfred A. Knopf Inc., New York, N.Y.

Bystrak, D. 1981. The North American Breeding Bird Survey. Stud. Avian Biol. 6:34-41.

Davis, A.M. and T.F. Glick. 1978. Urban ecosystems and island biogeography. Environ. Conser. 5:299-304.

DeGraaf, R.M. 1991. Breeding bird assemblages in managed northern hardwood forests in New England. p. 154-171. In: J. E. Rodiek and E. G. Bolen (eds.). Wildlife and habitats in managed landscapes. Island Press, Washington, D.C.

DeGraaf, R.M. and B.R. Payne. 1975. Economic values on non-game birds and some urban wildlife research needs. Trans. N. Amer. Wildl. Nat. Resour. Conf. 40:281-287.

Drake, J.A., H.A. Mooney, F. DiCastri, R. H. Groves, F.J. Kruger, M. Rejmanek, and M. Williamson. 1989. Biological invasions: a global perspective. John Wiley and Sons, New York, N.Y.

Faaborg, J., M. Brittingham, T. Donovan, and J. Blake. 1993. Habitat fragmentation in the temperate zone: a perspective for managers. p. 331-338. In: D. M. Finch and P. W. Stangel (eds.). Status and management of neotropical migratory birds. USDA Gen. Tech. Rep. RM-229.

Flather, C.H. and J.R. Sauer. 1996. Using landscape ecology to test the hypothesis about large-scale abundance patterns in migratory birds. Ecol. 77:28-35.

Geissler, P.H. and B.R. Noon. 1981. Estimates of avian population trends from the North American Breeding Bird Survey. Stud. Avian Biol. 6:42-51.

George, J.L. 1982. Urban wildlife. Penn. Agr. Exp. Sta. U.Ed. 82-868.

Gill, D. and P. Bonnett. 1973. Nature in the urban landscape: a study of city ecosystems. York Press, Baltimore, Md.

Gray, F. and H.M. Galloway. 1959. Soils of Oklahoma. Okla. Agr. Exp. Sta. Res. Rep. MP-56. Stillwater, Okla.

Grove, M. and M. Hohmann. 1992. Social forestry and GIS. J. For. 90: 10-15.

Hagan, J.M. and D.W. Johnston. 1992. Ecology and conservation of neotropical migrant land birds. Smithsonian Inst. Press, Washington, D.C.

Hamel, P.B. 1992. The land managerís guide to the birds of the south. The Nature Conservancy, Southeastern Region, Chapel Hill, N.C.

Harlan, J. R. 1957. Grasslands of Oklahoma. Okla. St. Univ., Stillwater, Okla.

Harrison, H. H. 1975. A field guide to the birds nests of 285 species found in the United States east of the Mississippi river. Houshton Mifflin Company, Boston, Mass.
Haub, C. and M. M. Kent. 1989. 1989 world population data sheet. Population Reference Bureau, Washington, D.C.

Hill, M. O. and H. G. Gauch. 1980. Detrended correspondence analysis: an improved ordination technique. Vegetatio 42:47-58.

Jarvinen, O. and R. A. Vaisanen. 1980. Quantitative biogeography of Finnish land birds as compared with regionality in other taxa. Ann. Zool. Fennici. 17:67-85.

Johnson, R. G. and S. A. Temple. 1986. Assessing habitat quality of birds nesting in fragmented tallgrass prairies. p. 245262. In: J. Verner, M. L. Morrison and C. J. Ralphm (eds.). Wildlife 2000: modeling habitat relationships of terrestrial vertebrates. Univ. Wis. Press, Madison, Wis.

Kalkhoven, J. and P. Opdam. 1984. Classification and ordination of breeding bird data and landscape attributes. p. 15-26. In: J. Brandt and P. Agger (eds.). Methodology in landscape ecological research and planning. Roskilde Univ. Centre, Roskilde, Denmark.

Kirsch, L. M. 1974. Habitat management considerations for prairie chickens. Wildl. Soc. Bull. 2:124-129.

Knick, S. T. and J. T. Rotenberry. 1995. Landscape characteristics of fragmented shrubsteppe habitats and breeding passerine birds. Conser. Biol. 9:1059-1071.

Knopf, F. L. 1986. Changing landscapes and the cosmopolitism of the eastern Colorado avifauna. Wildl. Soc. Bull. 14:132-142.

Knopf, F. L. 1994. Avian assemblages on altered grasslands. Stud. Avian Biol. 15:247-257.

Krummel, J. R., R. H. Gardner, G. Sugihara, R. V. Oíneill, and $P$. R. Coleman. 1987. Landscape patterns in a disturbed environment. Oikos 48:321-324.

Landres, P. B. 1992. Temporal scale perspectives in managing biological diversity. Trans. N. Amer. Wildl. Nat. Resour. Conf. 57:292-307.

Malanson, G. P. and L. Trabaud. 1987. Ordination analysis of components of resilience of Quercus coccifera garrigue. Ecol. 68:463-472.

Maurer, B.A. 1993. Biological diversity, ecological integrity, and neotropical migrants: new perspectives for wildlife management. p. 24-31. In: D. M. Finch and P. W. Stangel (eds.). Status and management of neotropical migratory birds. USDA Gen. Tech. Rep. RM-229.

Maurer, B.A. and S.G. Heywood. 1993. Geographic range fragmentation and abundance in neotropical migratory birds. Conser. Biol. 7:501-509.

McDonnell, M. J. and S. T. A. Pickett. 1990. Ecosystem structure and function along urban-rural gradients: an unexploited opportunity for ecology. Ecol. 71:1232-1237.
Okland, R.H., O.Eilertsen, and T. Okland. 1990. On the relationship between sample plot size and beta diversity in boreal coniferous forests. Vegetatio 87:187-192.

Palmer, M.W. 1993. Putting things in even better order: the advantages of canonical correspondence analysis. Ecol. 74:2215-2230.

Rodiek, J.E. 1991. Introduction. p. 3-10. In: J. E. Rodiek and E.G. Bolen (eds.). Wildlife and habitats in managed landscapes. Island Press, Washington, D.C.

Rotenberry, J.T. 1985. The role of habitat in avian community composition: physiognomy or floristics. Oecologica 67:213-217.

Roth, R.R. 1976. Spatial heterogeneity and bird species diversity. Ecol. 57:773-782.

Saetersdal, M. and H.J.B. Birks. 1993. Assessing the representativeness of nature reserves using multivariate analysis: vascular plants and breeding birds in deciduous forests, western Norway. Biol. Conserv. 65:121-132.

Samson, F.B. and F.L. Knopf. 1993. Managing biological diversity. Wildl. Soc. Bull. 21:509-514.

Scott, J.M., F. Davis, B. Csut, R. Noss, B. Bulterfield, C. Groves, H. Anderson, S. Caicco, F.O'Erchia, T.C. Edwards, Jr., J. Ulliman, and R.G. Wright. 1993. GAP analysis: a geographic approach to protection of biological diversity. Wildl. Monogr. 123:1-41.

Smith, L.C. 1975. Urban wildlife - is it wanted and needed? Can. Field Nat. 89:351-353.

Soil Conservation Service. 1981. Land resource regions and major land resource areas of the United States. USDA Soil Conser. Serv., Agr. Handb. 296. Washington, D.C.

Stoms, D.M., F. W. Davis, C.B. Cogan, M. D. Dainho, B.W. Duncan, and J.Scepan. 1983. Geographic analysis of California condor sighting data. Conserv. Biol. 7:148-159.

ter Braak, C.J.F. 1986. Canonical correspondence analysis: a new eigenvector technique for multivariate direct gradient analysis. Ecol. 67:1167-1179.

ter Braak, C.J.F. 1987. The analysis of vegetation-environment relationships by canonical correspondence analysis. Vegetatio 69:69-77.

ter Braak, C.J.F. 1988. CANOCO - a FORTRAN program for canonical community ordination. Microcomputer Power, Ithaca, N.Y.

Thompson, F. R., S. J. Lewis, J. Green, and D. Ewert. 1993. Status of neotropical migrant landbirds in the midwest: identifying species of management concern. p. 145-158. In: D. M. Finch and P. W. Stangel (eds.). Status and management of neotropical migratory birds. USDA Gen. Tech. Rep. RM-229. 
U.S. Department of Commerce, Economics, and Statistics Administration, Bureau of the Census. 1990. Census of population and housing, population and housing unit counts, Oklahoma. Government Printing Office, Washington, D.C.

Urban, D.L., and H.H. Shugart, Jr. 1984. Avian demography in mosaic landscapes: modeling paradigm and preliminary results. p. 273-280. In: J. Verner, M.L.
Morrison, and C.J. Ralph (eds.). Wildlife 2000: modeling habitat relationships of terrestrial vertebrates. Univ. Wis. Press, Madison, Wis.

Urban, D.L., A.J. Hansen, D.O. Wallin, and P. N. Halpin. 1992. Life-history attributes and biodiversity. Scaling implicators for global change. p. 173-195. In: O. T. Solbrig, H. M. van Emden, and G. W. J. van Gordt (eds.). Biodiversity and global change. Int. Union Biol. Sci., Monogr. No. 8.
West, N.E. 1993. Biodiversity of rangelands. J. Range Manage. 46:2-13.

Whisenant, S.G., and F.J. Wagstaff. 1991. Successional trajectories of a grazed salt desert shrubland. Vegetatio 94:133-140.

Wiens, J. A. 1974. Habitat heterogeneity and avian community structure in North American grasslands. Amer. Midl. Nat. 43:237-270.

Wilson, M.V. and C.L. Mohler. 1983. Measuring compositional change along gradients. Vegetatio 54:129-141.

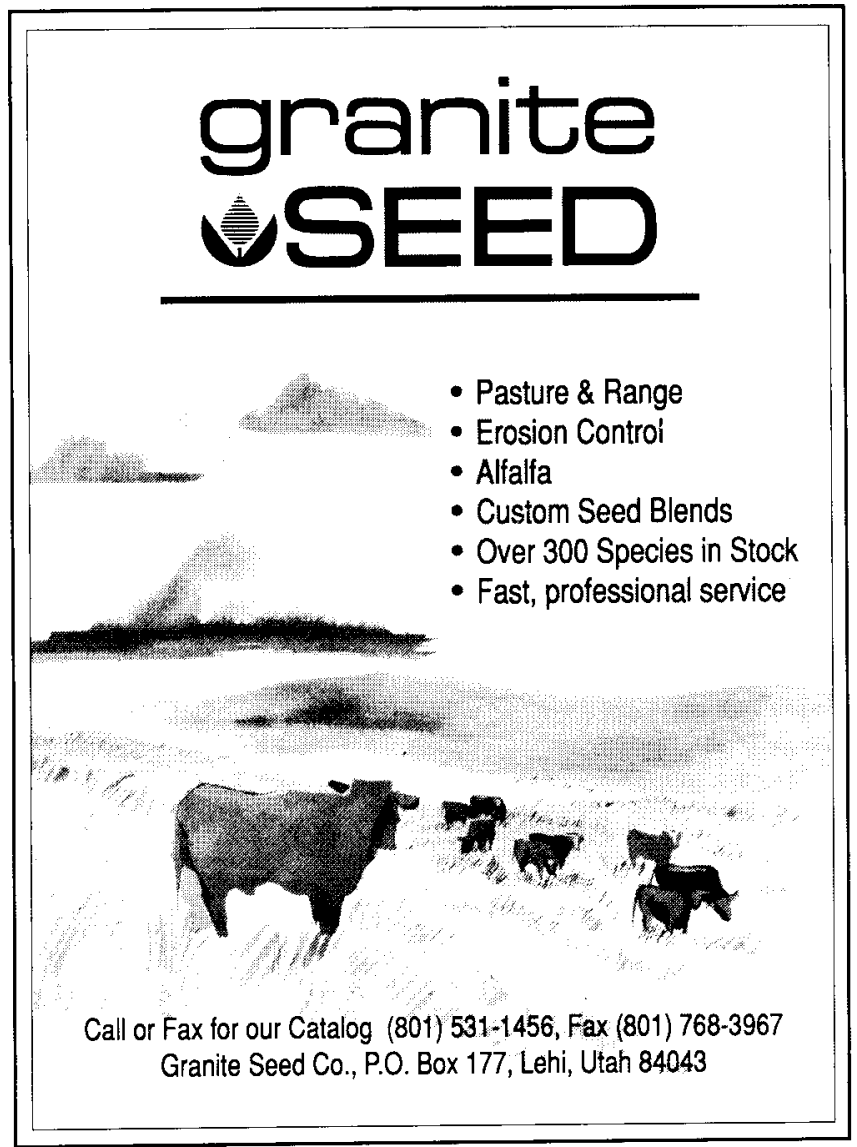

